\title{
Studies on the Pathogenesis of the Disturbance of the Carbohydrate Metabolism in the Alcohol fed rats
}

\author{
Kazuo KATSUMATA and Kozo YAMADA
}

Third Department of Internal Medicine, Nagoya University

Authors fed male albino rats for 210 days with the standard diet with alcohol or with glucose solution isocarolic to alcohol.

Following findings were obtained in alcohol fed rats.

i) GTT, PGTT and IST showed the disturbance of the carbohydrate metabolism.

ii) The incorporation of alanine-U-C $\mathrm{C}^{14}$ and glucose- $\mathrm{U}-\mathrm{C}^{14}$ into liver glycogen was lower than that of the control, that is, glycogenesis in alcohol fed group was apparently impaired.

iii) The incorporation of alanine- $\mathrm{U}-\mathrm{C}^{14}$ into blood glucose was higher than that of the control.

iv) In epididymal fat pad, glucose uptake and insulin effect on the incorporation of glucose-U-C $\mathrm{C}^{14}$ into expired $\mathrm{CO}_{2}$ were also disturbed. As above mention, the results suggest that alcohol feeding can induce the disturbance of carbohydrate metabolism, and that neither alcoholic fatty liver nor the increment of calory intake is responsible for this carbohydrate disturbance.

(See pp. 1109 1114) 


\section{アルコール長期投与白鼠にみられる 糖代謝異常に関する研究}

名古屋大学医学部第三内科

勝又一夫, 山田弘三

（昭和 45 年 9 月 24 日受付）

雄性白鼠を 210 日間，標準食に alcohol を添加して飼育すると，標準食に alcohol と等カロリーの glucose 液を加えて飼育した場合に比し，耐糖能の異常，インスリン感性の低下が出現する.

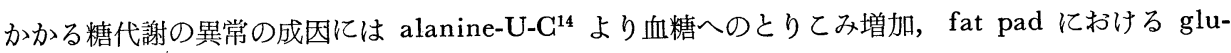
cose uptake 及びインスリン感性の低下ならびそ alanine-U-C ${ }^{14}$ 及び glucose-U- ${ }^{14} \mathrm{C}$ より肝 glycogen へのとりとみ低下などが関与すると思われる。乙れら糖代謝異常の成因を alcohol hypoglycemia との 関連で論じた。

緒 言

Alcohol (ethanol) の飲用で，ときに低血糖がくることはよく知られているが，糖代謝異常が惹起される こともまた事実である2). Alcohol hypoglycemia は飢餓あるいは low calory の摂取時に alcohol が飲用 された場合に発生する1).

Alcohol による糖代謝異常は，GTT の異常，インスリン感性の低下などが特徵的であり 2), alcohol を 連続投与した白鼠で見られる。 また慢性 alcohol 中毒患者でもしばしば GTT の異常が報告されている3). Alcohol 長期投与白鼠亿見られる糖代謝異常の成因については，肝が重要な役割を果たしていると思われる が，なおその詳細は不明である.

そこで本実験では，alcohol 投与白鼠の肝，fat pad， diaphragm の糖代謝を $2 ， 3$ の面より検討した. その結果, 肝の glycogenesis は抑制され, 肝の gluconeogenesis は増加し, 脂肪組織では glucose uptake とインスリン感性の低下が存在した. 本論文は, alcohol の摂取が単にカロリーの増加と脂肪肝を来たすの みではなく，大量の摂取が長期にわたれば肝及び脂肪組織の糖代謝にかなりの影響を与える事実を明らかに した.

\section{材 料と方 法}

雄性 Wister 系白鼠40匹を20匹ずつの 2 群に分け，それに $10 \%$ alcohol 水溶液を自由に飲ませ，合成食 で 210 日間飼育した．対照群は等カロリーの glucose 液を飲用せしめ，できるだけ alcohol 群と等カロリ 一となるように留意した。なお合成食及び vitamin 液の組成は既報によつた2．

飼去 200 日目に GTT, 201 日目に PGTT を施行した. GTT は 20\% glucose 水溶液を体重 $100 \mathrm{~g}$ あた り $1 \mathrm{ml}$ あて胃管で経口投与し，投与前及び投与後 $30^{\prime} ， 60^{\prime}, 90^{\prime}, 120^{\prime}, 180$ 分後に尾静脈より $0.05 \mathrm{ml}$ ずつ 採血し，Hagedorn-Jensen 氏法で血糖を測定した。 なお PGTT については glucose の投与 2 時間前及び 8 時間前に predonisolone $0.4 \mathrm{mg}$ を体重 $100 \mathrm{~g}$ あたりに腹腔内へ注射し，次いで GTT を前述の如くに行な つた. 飼育 202 日目にはインスリン感性 test を施行した. インスリン感性 test (IST) は regular インス リン 0.04unit を体重 $100 \mathrm{~g}$ あたり腹腔内へ注射し, 腹注前と腹注 $20^{\prime}, 30^{\prime}, 60^{\prime}, 90^{\prime}$ ，120 分後に尾静脈よ 


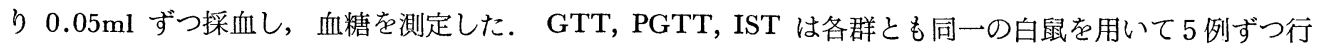
ない，血糖值は mean $\pm \mathrm{SE}$ で表わした。 Diaphragm, fat pad の glucose uptake は 203 日目に各群 5 例 ずつ白鼠を断頭屠殺し，以下の如き方法で測定された. Diaphragm, epididymal fat pad をとり出し氷冷 した Krebs ringer bicarbonate buffer を含むビーカーに入れて diaphragm muscle 及び fat pad の distal part を速やかに分離した. 次いで diaphragm, epididymal fat pad を $100 \mathrm{mg}$ 当てとり出し，そ れを 200mg\%の glucose を含有する Krebs ringer bicarbonate buffer $2 \mathrm{ml}$ を含むフラスコへ入れ，ゴ ム栓をし, $95 \% \mathrm{O}_{2}, 5 \% \mathrm{CO}_{2}$ の混合気相にして $37^{\circ} \mathrm{C} て ゙ 120$ 分間振悀 incubation した. Incubation 終了 後, medium の glucose 濃度を測定し, incubation 前の glucose 濃度より glucose uptake を計算した.

なお一部の実験では $0.5 \mu \mathrm{c}$ glucose-U-G ${ }^{14}$ をフラスコへ入れ，前述と同様に fat pad，diaphragm ととも に $95 \% \mathrm{O}_{2}, 5 \% \mathrm{CO}_{2}$ の気相で振蕰 incubation した. Incubation 終了後, $10 \mathrm{~N}_{2} \mathrm{SO}_{4} 0.4 \mathrm{ml}$ を medium に 入れて反応を止め, $\mathrm{CO}_{2}$ を発生せしめ, 次いでゴム栓よりつるした容器の中へ $1.8 \mathrm{~N} \mathrm{NaOH} 0.2 \mathrm{ml}$ を入れ, さらに1時間 incubation した. 次いで $\mathrm{NaOH}$ をとり出し, $\mathrm{BaSO}_{4}$ を加えて $\mathrm{BaCO}_{3}$ にし， gas flow counter で $\mathrm{C}^{14}$ の incorporation を測定した。なお自己吸収による補正を加え，さらに $\mathrm{BaCO}_{3}$ を入れる 前後の重量より $\mathrm{CO}_{2}$ の $\mathrm{mg}$ を出した. $\mathrm{C}^{14}$ の incorporation は $\mathrm{cpm} / \mathrm{mg} \mathrm{CO} 2$ として表わした. 205日目 には各群10匹ずつに glucose-U-C $\mathrm{C}^{14} 10 \mu \mathrm{C}$ を体重当 $100 \mathrm{~g}$ たりに腹注し，30分後に5 匹を断頭屠殺して肝を とり出した。次いで肺 glycogen を Montgomery 法4) で抽出し, その半分を gas flow counter で count し, 残りで肝 glyoogen を M. Dubois ${ }^{5}$ 法で測定して cpm/mg glycosen として肝 glycogen への $\mathrm{C}^{14}$ の

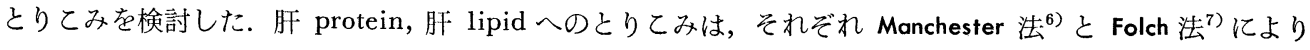
抽出して測定した。 また isotope を腹注 4 時間後にも各群 5 例ずつ断頭屠殺し, glucose-U-C $\mathrm{C}^{14}$ より肝 glycogen，蛋白，脂肪への $\mathrm{C}^{14}$ のとりてみを同様に検討した。 なお断頭特に血液を集め，血液中に残存してい る glucose-U-C $\mathrm{C}^{14}$ を Somogyi 法 ${ }^{8)}$ 及び Osazon 法 ${ }^{99}$ により測定した。なお肝脂肪は Bragdon 法 ${ }^{10)}$ ，肝蛋白 は Biuret 法 ${ }^{11)}$ でそれぞれ測定し, 肝脂肪, 肝蛋白への isotope のとりてみは cpm/mg lipid, cpm/mg protein で表わした。 なお 210 日目には残りの各群 5 匹ずつに alanine-U-G ${ }^{14} 10 \mu \mathrm{c}$ を腹注し， 4 時間後に断 頭屠殺して肝をとり出し血液を集め, 肝 glycogen, 血糖への $\mathrm{G}^{14}$ のとりとみと前述の如く検討した。

\section{実 験 成 績}

\section{GTT, PGTT, IST について}

飼育 200 日目に行なわれた GTT の成績は table 1 亿示す如く, alcohol 群では対照群に比して明白な 異常が存在した.

PGTT は table 1 の如く, 両群とも GTT の成績よりも悪く, 異常を示した. Alcohol 群の PGTT の 異常は対照群よりも明白で, 糖尿病型を示した。 また PGTT施行時に alcohol 群の一部に尿糖の排出をみ る白鼠があつた。

IST についても table 1 亿示したが, alcohol 群で明らかなインスリン感性の低下が存在した。即ち, alcohol 群ではインスリンによる血糖の低下が対照に比して少なかつた。 なお alcohol 群の 201 日目の平均 体重は $270 \mathrm{~g}$ で対照群の体重は $274 \mathrm{~g}$ であり，両群ともほぼ等しい体重の増加を示した。

2. Diaphragm, fat pad における glucose uptake と glucose-U-G' ${ }^{14}$ より $\mathrm{CO}_{2}$ へのよりこみについて

Table 2 の如く diaphragm の glucose uptake は対照及び alcohol の雨群に差異がない. Glucose uptake に及ぼす $1 \mathrm{~m}$ unit のインスリン作用も同様であつた。 とてろが epididymal fat pad の成績では table 2 の如く alcohol 群の glucose uptake は対照より明白に低下していた. Alcohol 群の glucose uptake の低下は $1 \mathrm{~m}$ unit のインスリンを加えた場合にも明らかで, glucose uptake に対するインスリン の効果の障害が示された. Glucose uptake は5 例ずつの mean $\pm \mathrm{SE}$ で表わした.

Fat pad, diaphragm そおける glucose-U-G $\mathrm{C}^{14}$ より $\mathrm{GO}_{2}$ へのとりとみは table 2 の右側と示した. Diaphragm においては glucose-U-C ${ }^{14}$ から $\mathrm{CO}_{2}$ へのとりてみもそれに及ぽす $1 \mathrm{~m}$ unit のインスリン 
Table 1. GTT, PGTT and IST of rat in alcohol and control group 1) GTT

\begin{tabular}{|c|c|c|c|c|c|c|}
\hline & Before & $30^{\prime}$ & $60^{\prime}$ & $90^{\prime}$ & $120^{\prime}$ & 180 midutes \\
\hline Alcohol group & $\begin{array}{l}118.3 \\
\pm 9.4\end{array}$ & $\begin{array}{l}178.6 \\
\quad \pm 13.7\end{array}$ & $\begin{array}{l}184.2 \\
\quad \pm 19.1\end{array}$ & $\begin{array}{l}161.5 \\
\pm 15.1\end{array}$ & $\begin{array}{l}138.9 \\
\pm 10.3\end{array}$ & $\begin{array}{r}134.6 \\
\quad \pm 8.3\end{array}$ \\
\hline Control group & $\begin{array}{l}92.1 \\
\pm 8.3\end{array}$ & $\begin{array}{l}134.4 \\
\quad \pm 18.9\end{array}$ & $\begin{array}{l}126.7 \\
\pm 13.4\end{array}$ & $\begin{array}{l}104.6 \\
\pm 9.4\end{array}$ & $\begin{array}{l}103.9 \\
\pm 7.9\end{array}$ & $\begin{array}{l}92.4 \\
\pm 7.4\end{array}$ \\
\hline
\end{tabular}

2) PGTT

\begin{tabular}{|c|c|c|c|c|c|c|}
\hline & Before & $30^{\prime}$ & $60^{\prime}$ & $90^{\prime}$ & $120^{\prime}$ & 180 minutes \\
\hline Alcohol group & $\begin{array}{l}123.5 \\
\quad \pm 9.9\end{array}$ & $\begin{array}{l}209.6 \\
\quad \pm 15.3\end{array}$ & $\begin{array}{l}214.7 \\
\quad \pm 13.3\end{array}$ & $\begin{array}{l}203.4 \\
\quad \pm 10.4\end{array}$ & $\begin{array}{l}167.1 \\
\pm 9.8\end{array}$ & $\begin{array}{l}149.0 \\
\pm 7.9\end{array}$ \\
\hline Control group & $\begin{array}{l}103.4 \\
\pm 7.8\end{array}$ & $\begin{array}{l}179.6 \\
\pm 14.7\end{array}$ & $\begin{array}{l}166.3 \\
\quad \pm 12.1\end{array}$ & $\begin{array}{l}154.1 \\
\quad \pm 10.3\end{array}$ & $\begin{array}{l}121.7 \\
\pm 9.4\end{array}$ & $\begin{array}{l}104.5 \\
\pm 5.7\end{array}$ \\
\hline
\end{tabular}

3) IST

\begin{tabular}{|c|c|c|c|c|c|c|}
\hline & Before & $30^{\prime}$ & $60^{\prime}$ & $90^{\prime}$ & $120^{\prime}$ & 180 minutes \\
\hline Alcohol group & $\begin{array}{l}115.3 \\
\pm 10.3\end{array}$ & $\begin{array}{c}104.4 \\
\pm 9.7\end{array}$ & $\begin{array}{l}99.4 \\
\quad \pm 7.7\end{array}$ & $\begin{array}{l}89.6 \\
\quad \pm 8.3\end{array}$ & $\begin{array}{l}96.2 \\
\quad \pm 7.1\end{array}$ & $\begin{array}{c}108.3 \\
\quad \pm 4.9\end{array}$ \\
\hline Control group & $\begin{array}{c}102.4 \\
\quad \pm 9.6\end{array}$ & $\begin{array}{l}64.3 \\
\quad \pm 9.4\end{array}$ & $\begin{array}{l}63.2 \\
\quad \pm 8.1\end{array}$ & $\begin{array}{l}63.2 \\
\quad \pm 8.1\end{array}$ & $\begin{array}{l}69.1 \\
\quad \pm 5.9\end{array}$ & $\begin{array}{l}104.3 \\
\quad \pm 5.3 \\
\end{array}$ \\
\hline
\end{tabular}

1) GTT

Glucose tolerance test was performed in both group on 200th day.

2) PGTT

Prednisolone glucose tolerance test was performed in both group on 201 th day.

3) IST

Insulin sensitivity test was performed in both group on 202th day.

Number in the table means the mean $\mathrm{mg} / \mathrm{dl}$ of blood glucose \pm S.E.

Table 2. Glucose uptake and the incorporation of glucose-U-G ${ }^{14}$ into expired $\mathrm{CO}_{2}$ at the diaphragm and fat pad in alcohol and control group.

\begin{tabular}{|c|c|c|c|c|c|c|c|c|}
\hline & \multicolumn{4}{|c|}{ Glucose uptake } & \multicolumn{4}{|c|}{ Glucose-U-C ${ }^{14} \longrightarrow \mathrm{CO}_{2}$} \\
\hline & \multicolumn{2}{|c|}{ Diaphragm } & \multicolumn{2}{|c|}{ Fat pad } & \multicolumn{2}{|c|}{ Diaphragm } & \multicolumn{2}{|c|}{ Fat pad } \\
\hline & $\begin{array}{c}\text { insulin } \\
(-)\end{array}$ & $\begin{array}{c}\text { insulin } \\
(+)\end{array}$ & $\begin{array}{c}\text { insulin } \\
(-)\end{array}$ & $\begin{array}{c}\text { insulin } \\
(+)\end{array}$ & $\begin{array}{c}\text { insulin } \\
(-)\end{array}$ & $\begin{array}{c}\text { insulin } \\
(+)\end{array}$ & $\begin{array}{c}\text { insulin } \\
(-)\end{array}$ & $\begin{array}{c}\text { insulin } \\
(+)\end{array}$ \\
\hline Alcohol group & $\begin{array}{l}8.13 \\
\pm 0.76\end{array}$ & $\begin{array}{l}13.01 \\
\quad \pm 1.65\end{array}$ & $\begin{array}{l}2.96 \\
\pm 0.5\end{array}$ & $\begin{array}{l}.89 \\
\pm 0.76\end{array}$ & $\begin{array}{r}3713.9 \\
\pm 131.2\end{array}$ & $\begin{array}{l}5970.6 \\
\pm 365.3\end{array}$ & $\begin{array}{c}4078.1 \\
\pm 149.2\end{array}$ & $\begin{array}{l}7900.4 \\
\pm 893.4\end{array}$ \\
\hline Control group & $\begin{array}{l}7.96 \\
\pm 1.03\end{array}$ & $\begin{array}{l}12.93 \\
\pm 1.74\end{array}$ & $\begin{array}{l}4.08 \\
\pm 0.41\end{array}$ & $\begin{array}{l}13.16 \\
\pm 0.70\end{array}$ & $\begin{array}{l}3811.7 \\
\quad \pm 179.4\end{array}$ & $\begin{array}{l}5760.4 \\
\pm 234.3\end{array}$ & $\begin{array}{l}3052.3 \\
\pm 153.2\end{array}$ & $\begin{array}{c}14100.3 \\
\pm 854.6\end{array}$ \\
\hline
\end{tabular}

Glucose uptake means the mean $\mathrm{mg}$ glucose $/ \mathrm{dl} \pm$ S.E. disappered by $100 \mathrm{mg}$ of diaphragm or fat pad.

The incorporation of glucose-U-G $\mathrm{C}^{14}$ into expired $\mathrm{C}^{14} \mathrm{O}_{2}$ means the mean incorporated ${ }^{14} \mathrm{G}$ radio-activity $\left(\mathrm{cpm} / \mathrm{mg} \mathrm{CO}_{2}\right) \pm$ S.E. by $100 \mathrm{mg}$ fat pad or $100 \mathrm{mg}$ diaphragm.

effect もともに alcohol 群と対照群で差はなかつた. ととろが fat pad では diaphragm と異り, alcohol 群で明白なインスリン effect の障害があつた。 しかしながら，インスリン無添加の場合の glucose-U-G ${ }^{14}$ の $\mathrm{CO}_{2}$ へのとりとみは glucose uptake と異り, 両群に差がみられなかつた.

3. Glucose-U-G ${ }^{14}$ より肝 glycogen, 肝 lipid, 肝 protein, 血糖へのとりこみについて

Table 3 の如く, alcohol 群では glucose-U-C ${ }^{14}$ の腹注30分後でも，4時間後でもともに肝 glycogen 
Table 3. The incorporation of glucose- $U-\mathrm{C}^{14}$ into liver glycogen, liver fat, liver protein and blood glucose of rats in alcohol and control group.

\begin{tabular}{|c|c|c|c|c|c|c|c|}
\hline & \multicolumn{3}{|c|}{ After 30 minutes } & \multicolumn{4}{|c|}{ After 4 hours } \\
\hline & $\begin{array}{c}\text { Liver } \\
\text { glycogen }\end{array}$ & $\begin{array}{c}\text { Liver } \\
\text { fat }\end{array}$ & $\begin{array}{c}\text { Liver } \\
\text { protein }\end{array}$ & $\begin{array}{c}\text { Liver } \\
\text { glycogen }\end{array}$ & $\begin{array}{c}\text { Liver } \\
\text { fat }\end{array}$ & $\begin{array}{c}\text { Liver } \\
\text { proteiu }\end{array}$ & $\begin{array}{l}\text { Blood } \\
\text { glucose }\end{array}$ \\
\hline Alcc & $\begin{array}{r}51.3 \\
\quad \pm 9.2\end{array}$ & $\begin{array}{r}29.6 \\
\quad \pm 7.3\end{array}$ & $\begin{array}{r}50.3 \\
\quad \pm 9.6 \\
\end{array}$ & $\begin{array}{l}597.1 \\
\quad \pm 73.4\end{array}$ & $\begin{array}{l}139.6 \\
\quad \pm 16.4\end{array}$ & $\begin{array}{l}209.6 \\
\quad \pm 14.6\end{array}$ & $\begin{array}{c}48913.6 \\
\pm 817.3\end{array}$ \\
\hline Control group & $\begin{array}{l}199.6 \\
\quad \pm 18.7\end{array}$ & $\begin{array}{l}54.1 \\
\quad \pm 9.6\end{array}$ & $\begin{array}{l}54.1 \\
\quad \pm 10.3\end{array}$ & $\begin{array}{l}998.7 \\
\pm 111.4\end{array}$ & $\begin{array}{l}136.7 \\
\quad \pm 11.3\end{array}$ & $\begin{array}{l}20.13 \\
\pm 16.9\end{array}$ & $\begin{array}{c}33914.6 \\
\pm 864.9\end{array}$ \\
\hline
\end{tabular}

Numbers in the table mean the mean incorporated $\mathrm{C}^{14}$ radio-activity \pm S.E. into liver glycogen (cpm/mg glycogen), liver fat (cpm/mg lipid), liver protein (cpm/ $\mathrm{mg}$ protein) and blood glucose ( $\mathrm{cpm} / \mathrm{mg}$ glucose per $\mathrm{dl})$.

への isotope のとりてみは対照に比して著明に低下していた．肝 protein，肝 lipid へのとりてみは30分 後，4時間後でもともに雨群で差がなかつた。一方，4時間後の glucose-U-G ${ }^{14}$ より血糖へのとりてみは， alcohol 群は対照よりも高くglucose の利用障害がうかがわれた。

Alanine-U-G ${ }^{14}$ を腹注し，4 時間後の肝 glycogen へのとりとみは table 4 の如く alcohol 群では対照

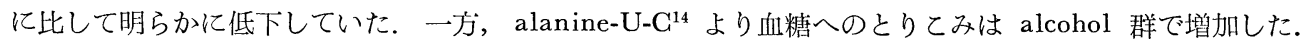
ての成續は alanine からの gluconeogenesis の增加を示唆する.

Table 4. The incorporation of Alanine-UG ${ }^{14}$ into liver glycogen and blood glucose of rats in alcohol and control group.

\begin{tabular}{c|c|c}
\hline \multirow{2}{*}{} & \multicolumn{2}{|c}{ After 4 hours } \\
\cline { 2 - 3 } & Liver glycogen & Blood glucose \\
\hline \hline Alcohol group & $296.7+43.6$ & $2916.7+516.4$ \\
Control group & $768.9+112.4$ & $1365.8+611.3$ \\
\hline
\end{tabular}

Number in the table means the mean incorporated $\mathrm{G}^{14}$ radio-activity \pm S.E. into liver glycogen (cpm/mg glycogen) and blood glucose $(\mathrm{cpm} / \mathrm{mg}$ glucose per $\mathrm{dl})$.

\section{考案}

Alcohol 投与白鼠で, diaphragm muscle そおける glucose の利用と insulin effect は対照と等しく正 常であつたが，fat pad の成績で glucose uptake とインズリン効果が明白に低下した. Glulose-U-G ${ }^{14}$ より $\mathrm{CO}_{2}$ へのとりてみは両群で差がなく, alcohol 群の fat pad でインスリン効果のみは低下していた. fat pad での glucose uptake の低下とインスリン作用の減弱の理由は不明であるが， isolate した fat pad， diaphragm の glucose uptake とインスリン効果は in vitro 亿 alcohol を加えると nonmetabolic な alcohol 作用によつて低下する事実から ${ }^{12)}$ 脂肪組織の membrone が in vivo の alcohol の投与によつて

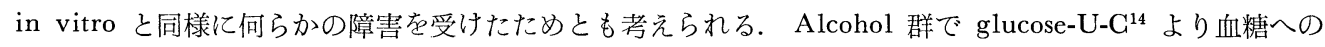
とりてみが増加していたととは GTT の異常とも一致しており，白鼠に投与した glucose の利用が障害さ れ，糖代謝異常の存在を示す. Alcohol 群でみられる GTT, IST の異常は既報と一致し2177) 今回行なわれ た PGTT の異常は明白に alcohol 群に於ける糖代謝異常の存在を示す.

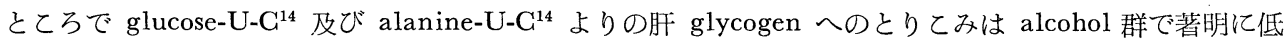
下しており，glycogenesis の低下を示す. 
一方, alanine-U-C ${ }^{14}$ より血糖へのとりとみは増加しており, alanine よりの gluconeogenesis の元進を 示す. すでに J.R. Williamson 等 ${ }^{13)}$ は肝灌流の実験で alcohol が alanine からの糖新生を増やす事を報告 しており，J. Ashmore 等は或る条件下で alcohol が G6 Pase を増加さすと報告し，共に我々の成績と一 致した ${ }^{14)}$. 一般に alcohol は hypoglycemia を菍起する事で知られており, alcohol hypoglycemia は $\frac{\mathrm{NADH}}{\mathrm{NAD}}$ の増加による肝での糖新生の抑制に起因するといわれているが, H.A. Krebsによれば alcohol によ る糖新生の抑制は種々の条件が必要である ${ }^{15)}$. 又 TCA cycle が正常であれば糖新生は alcohol で亢進し, 低下していると抑制されるとの成績もあり ${ }^{18)}$, 本実験条件では TCA cycle は正常である事と一致し2興味 深い.

以上要約すると, alcohol連続投与白鼠では fat pad で glucose の利用, insulin 效果の低下があり,さ

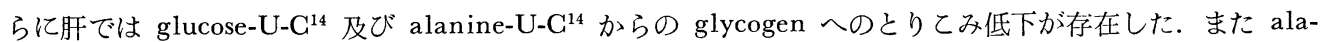
nine-U-C $\mathrm{C}^{14}$ より血糖へのとりてみは，明らかに増加していた。 これらの成䋶は, alcohol 投与白鼠の糖代 謝異常の成因に重要な役割を果たしていると思われる. とてろでアルコール群にみられた肝 glycogen への とりとみの低下は alcohol 性脂肪肝の一因を示すものと考元られ，脂肪肝と糖代謝異常との関連を示す。な

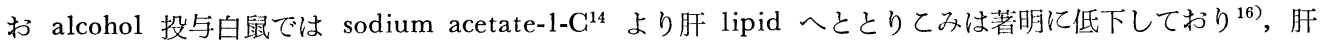
slice にわける glucose の oxidation は全く異常を認めなかつた2). 以上の成績から，alcohol 投与白鼠の 糖代謝の異常は飢餓，インスリン欠亡時にみられる糖代謝の異常と異質なものであり，また脂肪肝と関連す るが，それのみでは説明できないととを示す，又この糖代謝異常は alcohol の代謝課程に伴う metabolic effect と alcohol 自体の nonmetabolic effect により若起されたと思われるが，健全な膵がある限り代償 され，顕性糖尿病状態にはなり得ない，しかし，過度の飲酒は，糖尿病発症への誘因として，また糖尿病の 食飭療法を考光る上に注目すべきと思われる，今後さらにての alcohol 作用を検討する予定である.

結語

白鼠に alcohol（エタノール）を210日間連続投与し，脂肪肝では説明できない，糖代謝の異常が惹起さ れる事実を明らかにした。即ち, alcohol 群白鼠では

1) GTT, PGTT の異常を呈し, IST もインスリン作用の減弱を示した.

2) 朋では alanine-U-C ${ }^{14}$, glucose-U-C ${ }^{14}$ からの glycogen へのとりとみは低下し, glycogenesis の抑 制を示した.

3 ) Alanine-U-C ${ }^{14} よ り$ 血糖へのとりてみは增加し, gluconeogenesis の妄進を示した.

4) Fat pad では glucose uptake 及びィンスリン作用の低下があり, glucose-U-C ${ }^{14}$ より $\mathrm{CO}_{2}$ へのと りとみに対するインスリン効果も減弱していた。

通常, 膵が健全である限り, alcohol の投与で糖尿病状態にはならないが, 糖尿病時の食慨療法, 栄養と の関連から本報告は重要な知見と考える。

\section{文献}

1) Freinkel N., Singer D.L., Arky R.L., Bleicher S.J. and J.B. Anderson : Alcohol hypoglycemia. J. Clinic, Invest $42: 1112,1963$

2) Katsumata K. : The effect of various diet on the disturbance of lipid and carbohydrate metabolism of rat fed with alcohol. Japan J. stud., Alcohol 3(3.4) : 124, 1968 3) Karlan S.C. and Cohn C. : Glucose tolerance test in chronic alcoholism. Am. J.

Psychiatry $103: 247,1946$

Biochem. Biophys. $67: 378,1957$

4) Montgomery R. : The determination of liver glycogen. Arch.

5) Dubois M. : Determination of polysoccharide. Analytical, chem $29: 350,1956$

6) Manchester K.L.and Krahl M.E. : Insulin on the incorporation of $\mathrm{C}^{14}$ from $\mathrm{C}^{14}$ labeled carboxylic acid and bicarbonate into the protein of isolated rat diaphragm. $\mathrm{J}$. Biol. Chem., $234: 2938,1959$

7) FolchJ., Lees M. and Sloane stanly G.H : A simple method 
for the isolation and purification of total lipides from animal tissues. J. Biol. Chem. $226: 497,1957$ 8) Somogyi M : A method for the preparation of blood filtrates for the determination of sugar. J. Biol. chem. 86 : 655, $1930 \quad$ 9) Sterm M., Wag11 S.R. Swaney M.J. and Ashmore J. : Studies on experimental diabetes. J. Biol. chem. $238: 12,1963$

10) Bragdon J.H. : Colorimetric determination of blood lipides. J. Biol. chem. $190: 513,1951$ 11) Gornali G., Bardawill J. and David M.M. : Determination of serum proteins by means of the biuret reaction. J. Biol. chem. 177 : $751.1949 \quad$ 12) Unpublish data. 13$)$ Williamson J.R., Olson M.S., Browining E.T. and Scholz R. : Control of citric acid cycle, p. 207 The energy level and metabolic control in mitochondria. Adriatica Editrice, Bari 1969. ed by Papa S., Tayer J.M., Quagliarello E. andSlatar E.C. 14) Nelson P., Wagle S.R., and Ashmore J. : Studies on ethanol-induced stimulation of glucose-6-phosphatase activity. Metabolism 19(5) : 349, 1970

15) Krebs H.A. : The effect of ethanol on the metabolic activities on the liver. Advance in Enzyme regulation. 6:467, 1968 16）勝又一夫，山田弘三：アルコール脂肪肝の高脂肪食による促進と高蛋白食による抑制. 日消会誌，65 (1) : 69, 1968 17）勝又一夫：糖尿病と alcohol に関する実験的並びに臨床的研究. 日本内分泌， 38(10) : 1033, 1963. 18) Freinkel N., Cohen A.K., Arky R.A., Foster A.S. : Alcohol hypoglycemia. J. Clinic. Invest $25: 76,1965$. 